\title{
Changes in performance and wear of small diesel engine during durability test
}

\begin{abstract}
Changes in engine performance and efficiency, the tightness of ring-pack and wear of piston group parts during longlasting bench durability test were investigated. The tests were conducted on 2 modern automotive diesel engines. The parameters analysed improved in the initial period of engine operation and then they started to deteriorate gradually; however, the rates of change were different for different parameters. The rate of change was the highest in the case of lubricating oil consumption (100\% increase during the test). The blowby increased in that period of time by 25-60\%, depending on the condition of engine operation. The changes in power and specific fuel consumption were much smaller-only a few percent. Moreover, using the previously developed method utilizing the simulations made with the use of the ringpack model, the durability of the piston group was predicted. The predicted durability was equal to $300,000 \mathrm{~km}$.
\end{abstract}

Key words: durability, wear, cylinder, ring, blow-by, oil consumption

\section{Zmiany parametrów pracy oraz zużycie małego silnika o zapłonie samoczynnym podczas próby trwałościowej}

\begin{abstract}
W artykule zaprezentowano analizę zmian mocy i sprawności silnika oraz szczelności układu tłok-pierścienie-cylinder, a także zużycia elementów silnika podczas dlugotrwatych badań stanowiskowych. Obiektem badań byt nowoczesny, samochodowy silnik o zapłonie samoczynnym. Wartości analizowanych parametrów uległy poprawie w początkowym okresie pracy silnika, po czym zaczęty ulegać stopniowemu pogarszaniu, przy czym szybkość zmian dla poszczególnych parametrów była różna. Najszybciej wraz z czasem pracy silnika wzrastało zużycie oleju silnikowego (wzrost w czasie testu o około 100\%). Natężenie przedmuchów spalin wzrosto $w$ tym czasie od 25 do 60\%, w zależności od warunków pracy silnika, natomiast moc i jednostkowe zużycie paliwa zmienity się tylko o kilka procent. Ponadto, z wykorzystaniem opracowanej wcześniej metody, bazującej na symulacjach prowadzonych z użyciem matematycznego modelu uszczelnienia pierścieniowego, dokonano oceny trwałości zespotu TPC silnika. Prognozowana trwałość wyniosta $300000 \mathrm{~km}$.
\end{abstract}

Słowa kluczowe: trwałość, zużycie, cylinder, pierścień, przedmuchy spalin, zużycie oleju silnikowego

\section{Introduction}

The piston group dictates the tightness of the combustion chamber. Component wear increases blow-by and oil consumption and so causes a loss of power, energy efficiency and an increase in emissions.

Currently, the tendency for increasing unit power means that the constituent parts of the piston group are subjected to increasing mechanical and thermal loads, which causes quicker wear. Experience from servicing indicates, that a large increase in the power density affects the wear of more loaded engine parts, and the durability and reliability of whole engines.

Engineers try to improve the design of engines so that durability and reliability do not deteriorate despite the more difficult conditions of operation. Before being put into production, engines are subjected to harsh durability tests.

In this paper the results of bench durability tests of a car diesel engine are presented. The engine tested was a development version of an engine with power increased by $30 \%$ relative to the base version. The results of the piston group durability prediction made with the use of the ring-pack model are also presented in the paper.

\section{Tested engine and test method}

The object of the research was a 4-cylinder, turbocharged, $1.3 \mathrm{dm}^{3} \mathrm{CI}$ engine with turbocharged air cooling and EGR.

\section{Wstęp}

Zespół tłok-pierścienie-cylinder (TPC) decyduje o szczelności komory spalania. Zużycie elementów tego zespołu powoduje wzrost natężenia przedmuchów spalin do skrzyni korbowej oraz zużycie oleju silnikowego, a więc zmniejszenie mocy i sprawności energetycznej silnika oraz zwiększenie stężeń niepożądanych składników spalin.

Panująca obecnie tendencja do zwiększania mocy jednostkowej powoduje, że elementy zespołu TPC silnika spalinowego poddawane są coraz większym obciążeniom mechanicznym i cieplnym, co sprzyja szybszemu ich zużywaniu. Doświadczenia z eksploatacji wskazują, że obserwowane obecnie duże zwiększanie wysilenia silników nie pozostaje bez wpływu na zużycie bardziej obciążonych elementów i ich trwałość oraz niezawodność i trwałość całych silników.

Konstruktorzy starają się udoskonalać konstrukcję poszczególnych zespołów silnika, tak aby trwałość i niezawodność nie uległy pogorszeniu, mimo trudniejszych warunków pracy. Przed wprowadzeniem do produkcji silniki poddaje się badaniom trwałościowym.

W niniejszym artykule zaprezentowano wyniki uzyskane podczas stanowiskowych badań trwałościowych samochodowego silnika o zapłonie samoczynnym. Badany silnik jest rozwojową wersją silnika o zwiększonej o 30\% mocy, 
According to the producer, the engine had maximum power of $66 \mathrm{~kW}$ at $4000 \mathrm{rpm}$ and max torque of $200 \mathrm{~N} \cdot \mathrm{m}$ at 1750 $2250 \mathrm{rpm}$. The engine had 4 valves per cylinder, a common rail fuel system with direct injection, a cast iron block with cylinder bores of nominal diameter $69.6 \mathrm{~mm}$. Honed cylinder liners in their upper area had narrow, deep grooves, made with laser treatment (Fig. 1). This solution could reduce wear of the piston group and oil consumption. The stroke of the piston was $82 \mathrm{~mm}$. The engine had a typical ring system: a rectangular top compression ring with a barrel shape, a chromium-plated face, a tapered second compression ring and a double bevelled oil ring with a chromium-plated face and a coil spring. The aluminium piston had a cast iron insert under the top compression ring and a cooling gallery.

The engine was a development version of the original, which had maximum power of $51 \mathrm{~kW}$ and max torque of $180 \mathrm{~N} \cdot \mathrm{m}$. The main elements different from the original version were: the injectors, the high pressure pump, the turbocharger, the inlet cylinder head ducts and the pistons. The pistons used in the $66 \mathrm{~kW}$ version had a slightly different shape of combustion chamber, but first of all, they had cooling galleries, which enabled the temperature of upper part of the piston to be maintained at an acceptable level.

The tests were conducted on two engines. Before testing, the engines were partially disassembled and geometrical measurements of selected parts were made. After assembly and installation on the test bench, the engines were subjected to a four-hour run-in. Then, each of the engines underwent a long-term durability test, during which they operated under heavy load conditions in accordance with the elementary cycle (Fig. 2). During the test, the cycle was repeated 336 times. Before, after and during the durability test (about every 42 elementary cycles), speed characteristics and other measurements were performed to determine the parameters of the engine including blow-by and oil consumption. The total time of operation of each engine during the test was about 1200 hours.

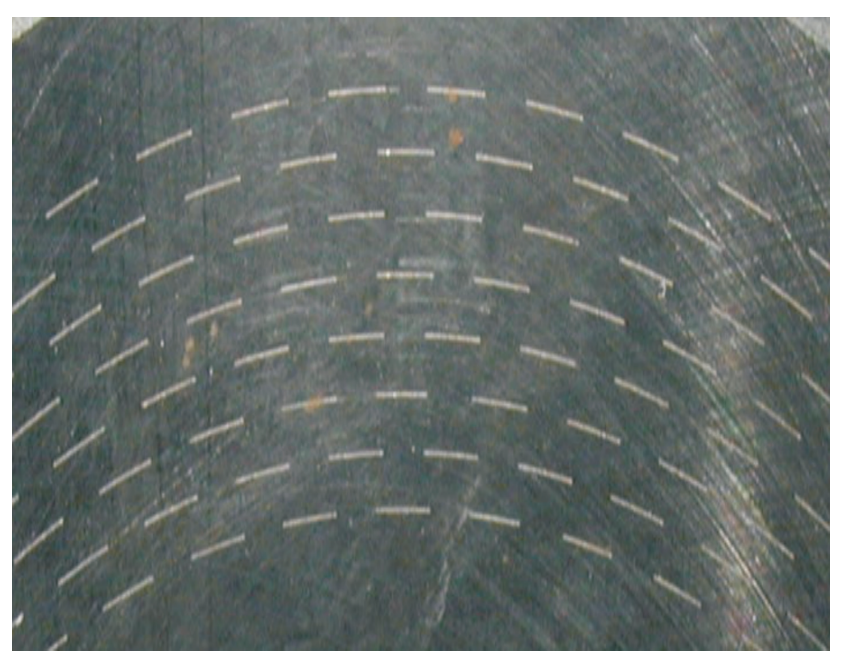

Fig. 1. Cylinder surface with laser burnt grooves

Rys. 1. Tuleja cylindrowa z laserowo wypalonymi zasobnikami olejowymi w stosunku do silnika bazowego. Zaprezentowano również wyniki badań symulacyjnych trwałości zespołu TPC tego silnika, przeprowadzonych z wykorzystaniem modelu uszczelnienia pierścieniowego.

\section{Obiekt i metoda badań stanowiskowych}

Obiektem badań był 4-cylindrowy, turbodoładowany silnik o zapłonie samoczynnym o objętości skokowej 1,3 $\mathrm{dm}^{3} \mathrm{z}$ chłodzeniem powietrza doładowującego i recyrkulacją spalin. Według danych producenta silnik miał moc maksymalną 66 kW osiąganą przy $4000 \mathrm{obr} / \mathrm{min}$ oraz maksymalny moment obrotowy $200 \mathrm{~N} \cdot \mathrm{m}$ w zakresie $1750-2250 \mathrm{obr} / \mathrm{min}$. Silnik posiadał 4 zawory na cylinder, układ wtryskowy typu common rail z bezpośrednim wtryskiem paliwa do cylindra, żeliwny blok z cylindrami o nominalnej średnicy 69,6 mm. Honowane tuleje cylindrowe miały w górnej części wąskie, głębokie rowki (zasobniki oleju smarującego) wykonane z wykorzystaniem obróbki laserowej (rys. 1). Rozwiązanie to miało na celu zmniejszenie zużycia elementów układu TPC oraz ilościowego zużycia oleju silnikowego. Skok tłoka badanego silnika wynosił $82 \mathrm{~mm}$. Silnik posiadał typowy układ pierścieniowy, w skład którego wchodziły: pierwszy prostokątny pierścień uszczelniający z baryłkową, chromowaną powierzchnią czołową, drugi stożkowy pierścień uszczelniający oraz dwuwargowy pierścień zgarniający z chromowanymi powierzchniami czołowymi i ze sprężyną spiralną. Aluminiowy tłok posiadał żeliwną wkładkę pod pierwszy pierścień uszczelniający oraz kanały chłodzące.

Badany silnik był rozwinięciem wyjściowej wersji silnika, która miała moc maksymalną $51 \mathrm{~kW}$ i maksymalny moment obrotowy $180 \mathrm{~N} \cdot \mathrm{m}$. Główne elementy różniące badany silnik od wersji wyjściowej to: wtryskiwacze, pompa wysokiego ciśnienia, turbosprężarka, kanały dolotowe w głowicy oraz łłoki. Tłoki zastosowane w wersji $66 \mathrm{~kW}$ miały nieco zmieniony kształt komory spalania, ale przede wszystkim posiadały kanały chłodzące, dzięki którym udało się utrzymać temperaturę górnej części tłoka na akceptowalnym poziomie.

Badaniom stanowiskowym poddano dwa egzemplarze silnika. Przed badaniami silniki częściowo zdemontowano i przeprowadzono pomiary geometryczne wybranych elementów. Po ponownym zmontowaniu silników i umieszczeniu ich na stanowisku hamownianym, przeprowadzono czterogodzinne ich docieranie. Następnie przeprowadzono długotrwałe testy trwałościowe, podczas których każdy z silników pracował w warunkach dużych obciążeń według elementarnego cyklu (rys. 2). W czasie testu cykl ten był powtarzany 336 razy. Przed, po i w trakcie testu trwałościowego, co około 42 cykle elementarne, wykonywano charakterystyki prędkościowe oraz inne pomiary mające na celu ustalenie parametrów silnika, w tym natężenie przedmuchów spalin i zużycie oleju silnikowego. Łączny czas pracy każdego silnika podczas badań wynosił ok. 1200 godzin.

Natężenie przedmuchów spalin mierzono za pomocą przepływomierza AVL 4040-A02 Blow-by Meter podczas wykonywania charakterystyk prędkościowych pełnej mocy oraz przy małym obciążeniu silnika (moment obrotowy równy $20 \mathrm{~N} \cdot \mathrm{m}$ ). W celu ustalenia zużycia oleju silnikowego 


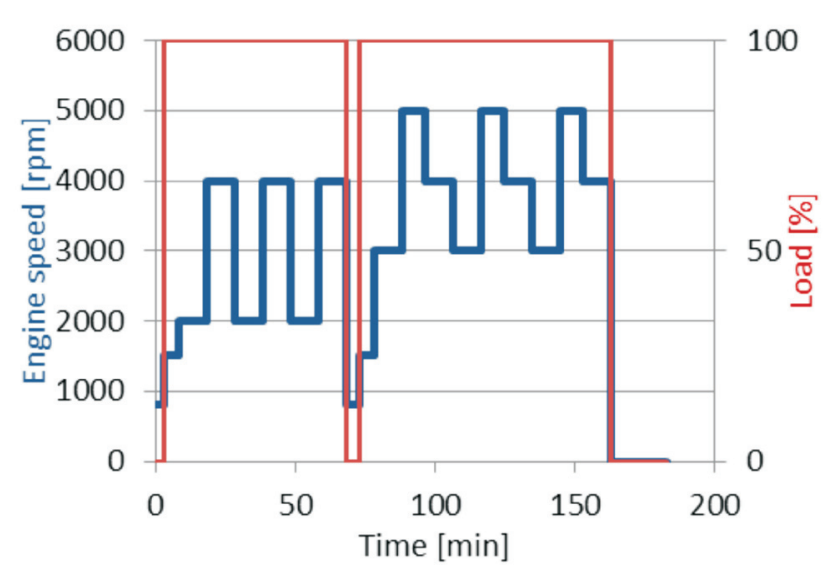

Fig. 2. Elementary cycle of the durability test Rys. 2. Cykl elementarny testu trwałościowego

The blow-by was measured by an AVL 4040-A02 Blowby Meter during engine speed characteristic measurements for full and low (torque equal to $20 \mathrm{~N} \cdot \mathrm{m}$ ) loads. Oil consumption was determined by weighing the oil drained from the oil sump before and after the four-hour test during which the engine worked at a steady-state condition at $3600 \mathrm{rpm}$. The oil consumption tests were performed for three engine loads: $100 \%, 33 \%$, and $20 \mathrm{~N} \cdot \mathrm{m}$.

After the end of the durability test, the engines were disassembled and micrometric measurements were carried out again. The cylinder diameters were measured at 15 depths and in two directions: parallel and perpendicular to the main engine axis with the use of the two-point bore gauge. The heights and widths of the rings were measured at 5 points: near the piston-ring joint, opposite the piston-ring joint and in the plane perpendicular to the ring joint. Ring gaps were measured after placing the ring into a benchmark sleeve.

\section{Results of research}

The results of the measurements for two engines were averaged and mean values were taken for further analysis. The changes in performance (power at $4000 \mathrm{rpm}$ and torque at $2000 \mathrm{rpm}$ ) and in engine efficiency (specific fuel consumption at 4000 and $2000 \mathrm{rpm}$ ) during the durability test are presented in Fig. 3. The changes in the parameters of the combustion chamber tightness (the blow-by at 2000 rpm and $4000 \mathrm{rpm}$, and oil consumption at different engine loads) are presented in Figs 4 and 5.

All of the analysed parameters, except for the power at $4000 \mathrm{rpm}$, got better in the first period of engine operation, and then they started to deteriorate gradually. However, subsequent values of particular parameters as a function of time did not always change monotonically. Therefore, a regression analysis was applied to assess the changes of the parameters as a function of time. In this analysis, the results of the first measurements, made before the durability test $(t=0)$, were ignored - it was assumed that the improvement in the values of the parameters observed in the first period of engine operation was associated with the run-in of the engines and that the run-in process had finished before the przeprowadzano tzw. próby olejowe. Ilość zużytego oleju wyznaczano na podstawie pomiarów masy zlanego oleju z miski olejowej przed i po 4-godzinnym teście silnikowym, w czasie którego silnik pracował w ustalonych warunkach z prędkością obrotową 3600 obr/min. Próby olejowe wykonywano przy trzech obciążeniach silnika: 100\%, 33\% i $20 \mathrm{~N} \cdot \mathrm{m}$.

Po zakończeniu badań stanowiskowych silniki zdemontowano i ponownie poddano pomiarom mikrometrycznym. Średnice tulei cylindrowych mierzono za pomocą dwupunktowej średnicówki na 15 głębokościach, w dwóch kierunkach: równoległym i prostopadłym do osi głównej silnika. Wysokości i szerokości pierścieni mierzono w 5 punktach: w okolicach zamka, naprzeciw zamka oraz w płaszczyźnie prostopadłej do płaszczyzny zamka. Luz w zamku pierścienia mierzono po umieszczeniu go w tulei wzorcowej.

\section{Wyniki badań stanowiskowych}

Wyniki pomiarów dla obu badanych silników uśredniono i dalszej analizie poddano wartości średnie. Na rysunku 3 zaprezentowano zmiany osiągów silnika (moc przy 4000 obr/min oraz moment obrotowy przy 2000 obr/min) i jego sprawności (jednostkowe zużycie paliwa przy 4000 i 2000 obr/min) w czasie testu trwałościowego, a na rys. 4 i 5 przedstawiono zmiany parametrów charakteryzujących szczelność komory spalania (natężenie przedmuchów spalin przy pełnym i małym obciążeniu silnika przy 2000 i 4000 obr/min oraz ilościowe zużycie oleju silnikowego wyznaczone podczas prób olejowych przy różnych obciążeniach silnika).

Wszystkie z omawianych parametrów, oprócz mocy przy $4000 \mathrm{obr} / \mathrm{min}$, uległy poprawie w pierwszym okresie pracy silnika, po czym zaczęły ulegać stopniowemu pogarszaniu. Jednak kolejne wartości poszczególnych parametrów w funkcji czasu pracy silnika nie zawsze zmieniały się w sposób monotoniczny. W związku z powyższym do oceny zmian analizowanych wielkości w czasie zastosowano analizę regresji, przy czym w analizach pominięto wyniki otrzymane w pierwszych pomiarach, tj. przed testem trwałościowym $(\mathrm{t}=0)$. Przyjęto, że obserwowana w początkowym okresie pracy silnika poprawa parametrów związana jest z docieraniem silnika i że proces docierania zakończył się przed wykonaniem drugiego pomiaru (ok. 150 godzin pracy silnika). Obliczono współczynniki korelacji liniowej pomiędzy wartościami badanych parametrów i czasem pracy silnika oraz zbadano istotność korelacji. Dla wszystkich analizowanych parametrów korelacja była istotna na poziomie istotności 0,05 [5]. Mimo że w niektórych przypadkach aproksymacja wielomianem drugiego stopnia dawała lepsze dopasowanie do wyników pomiarów (większa wartość współczynnika determinacji), to we wszystkich przypadkach ocenę zmian wartości parametrów przeprowadzono, opierając się na funkcji liniowej.

Ze wszystkich analizowanych parametrów najszybciej wraz z czasem wzrastało zużycie oleju silnikowego - wzrost w zakresie od 100 do 1200 godzin czasu pracy silnika o $108 \%, 96 \%$ i 113\%, odpowiednio przy obciążeniach 100\%, $33 \%$ i $20 \mathrm{~N} \cdot \mathrm{m}$. 


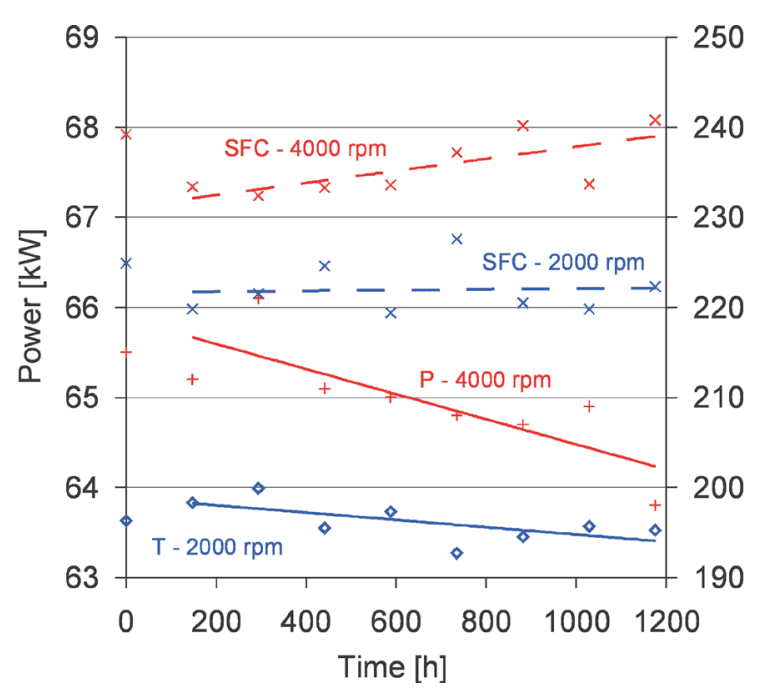

Fig. 3. Changes in power and specific fuel consumption at $4000 \mathrm{rpm}$ and torque and specific fuel consumption at $2000 \mathrm{rpm}$

Rys. 3. Zmiany mocy i jednostkowego zużycia paliwa przy prędkości obrotowej 4000 obr/min oraz momentu obrotowego i jednostkowego zużycia paliwa przy $2000 \mathrm{obr} / \mathrm{min}$

second measurements were made (before 150 hours of engine operation). Correlation coefficients between the investigated parameters and engine operating time were calculated, and the significance of the correlation was tested [5]. The correlation was significant at the 0.05 level for all parameters analysed. Although in the case of a few parameters, an approximation with a 2 nd degree polynomial better fitted the results of the measurements (with a higher value of determination coefficient), the assessment of the changes in values of all parameters was based on the linear function.

Of all parameters analysed, the oil consumption as a function of time was changing the fastest - increases of $108 \%, 96 \%$ and $113 \%$ at loads: $100 \%, 33 \%$, and $20 \mathrm{~N} \cdot \mathrm{m}$, respectively, in the range from 100 to 1200 hours of engine operation time.

The changes in blow-by were also significant, but they depended more on the condition of engine operation. At low loads $(20 \mathrm{~N} \cdot \mathrm{m})$, both at $2000 \mathrm{rpm}$ and $4000 \mathrm{rpm}$, blow-by increased by $25 \%$ in the range of $100-1200$ hours of engine operation. In the same range of time, blow-by at full load and $2000 \mathrm{rpm}$ increased by $37 \%$, while at full load and 4000 rpm - by $61 \%$.

The changes in engine performance (power, torque) in the analysed range of time, both at $2000 \mathrm{rpm}$ and 4000 rpm were similar - a drop of less than $2.5 \%$. Specific fuel consumption at $4000 \mathrm{rpm}$ in the same timeframe increased by $3.4 \%$ and at $2000 \mathrm{rpm}$ it practically didn't change (an increase of $0.2 \%$ ).

Similarly to the rate of change for the run-in engine, the relative change in the first period of engine operation was the biggest in the case of oil consumption. Oil consumption measured after 150 hours of engine operation was smaller than measured before the durability test, by $38 \%, 31 \%$, and $10 \%$ at the loads: $100 \%, 33 \%$ and $20 \mathrm{~N} \cdot \mathrm{m}$, respectively. In this timeframe the blow-by at low load decreased by $3 \%$ at $2000 \mathrm{rpm}$ and by $9 \%$ at $4000 \mathrm{rpm}$. At full load the blow-by

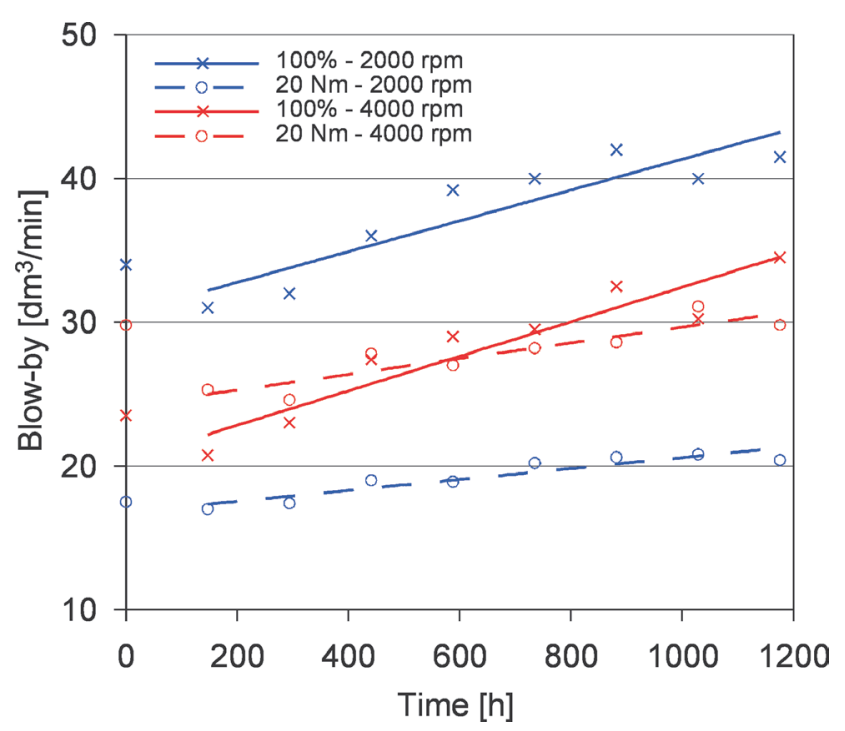

Fig. 4. Changes in blow-by at full and small engine load at 2000 and $4000 \mathrm{rpm}$

Rys. 4. Zmiany natężenia przedmuchów spalin przy pełnym i małym obciążeniu silnika i prędkościach obrotowych 2000 i 4000 obr/min

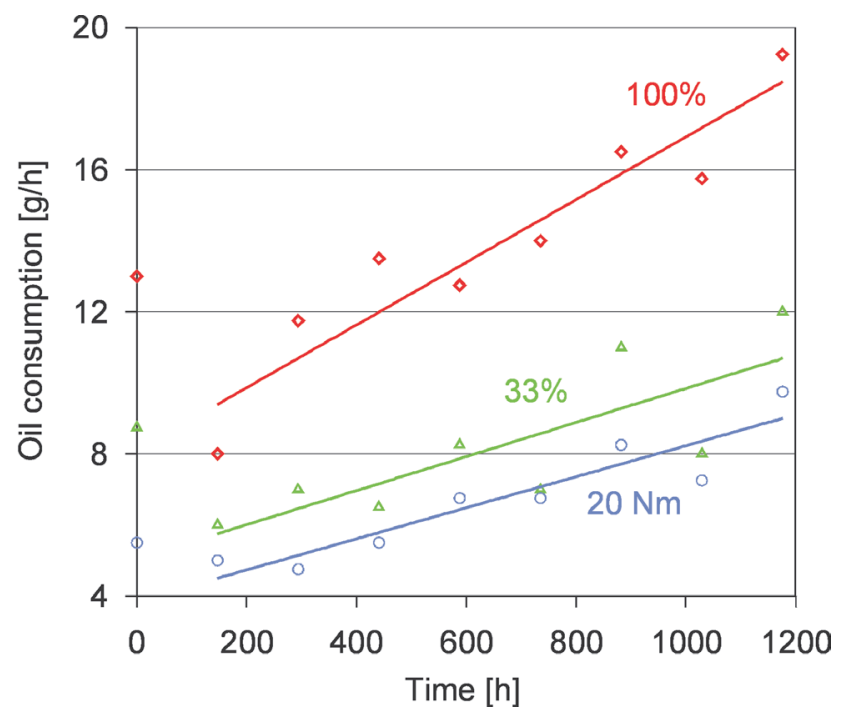

Fig. 5. Changes in oil consumption at various engine loads

Rys. 5. Zmiany ilościowego zużycia oleju silnikowego przy różnych obciążeniach silnika

Również zmiany natężenia przedmuchów spalin do skrzyni korbowej były znaczne, ale ich wartości zależały od warunków pracy silnika. Przy małych obciążeniach (20 $\mathrm{N} \cdot \mathrm{m}$ ), zarówno przy prędkości 2000 obr/min, jak i 4000 obr/min, natężenie przedmuchów spalin wzrosło o ok. $25 \%$ w zakresie 100-1200 godzin pracy silnika. W tym samym przedziale czasu natężenie przedmuchów spalin przy pełnym obciążeniu i $2000 \mathrm{obr} / \mathrm{min}$ wzrosło o $37 \%$, natomiast przy pełnym obciążeniu i $4000 \mathrm{obr} / \mathrm{min}$ - o 61\%.

Zmiany osiągów silnika (moc, moment) w analizowanym zakresie czasu jego pracy, zarówno przy prędkości obrotowej $2000 \mathrm{obr} / \mathrm{min}$, jak i $4000 \mathrm{obr} / \mathrm{min}$, były zbliżone - nastąpiło zmniejszenie o niecałe 2,5\%. Jednostkowe zużycie paliwa przy 4000 obr/min w tym czasie zwiększyło się 


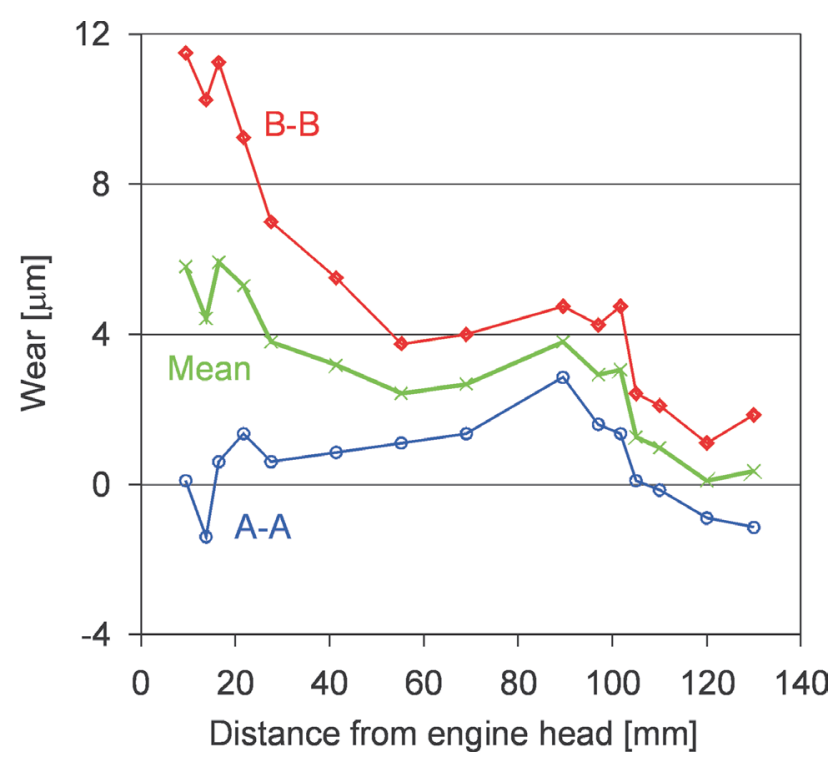

Fig. 6. Wear of cylinder liner in planes: perpendicular (B-B) and parallel (A-A) to the main engine axis

Rys. 6. Zużycie tulei cylindrowej w płaszczyznach: prostopadtej (B-B) i równolegtej (A-A) do osi silnika

decreased by $15 \%$ at $2000 \mathrm{rpm}$ and by $12 \%$ at $4000 \mathrm{rpm}$. Specific fuel consumption, both at 2000 and $4000 \mathrm{rpm}$, decreased by about $2.5 \%$ in this period of engine operation. The changes in power were small: an increase of $1 \%$ at 2000 $\mathrm{rpm}$ and a decrease of $0.5 \%$ at $4000 \mathrm{rpm}$.

Cylinder liner wear (the difference in diameter measured before and after the durability test) averaged for all cylinders of the two engines is shown in Fig. 6. The diameters of cylinder liners in the plane parallel to the engine axis didn't change a lot, but in the perpendicular plane they grew much more, especially in the top part of the liner. It must be assumed, that the changes in diameters were the results of both wear and deformation. Averaged values for both directions show that greater wear of the cylinder liner occurred in the area of the ring pack dead centers, especially the top one. The increases in ring gaps and decreases in the height of particular rings obtained in the testing are shown in Figs 7 and 8.

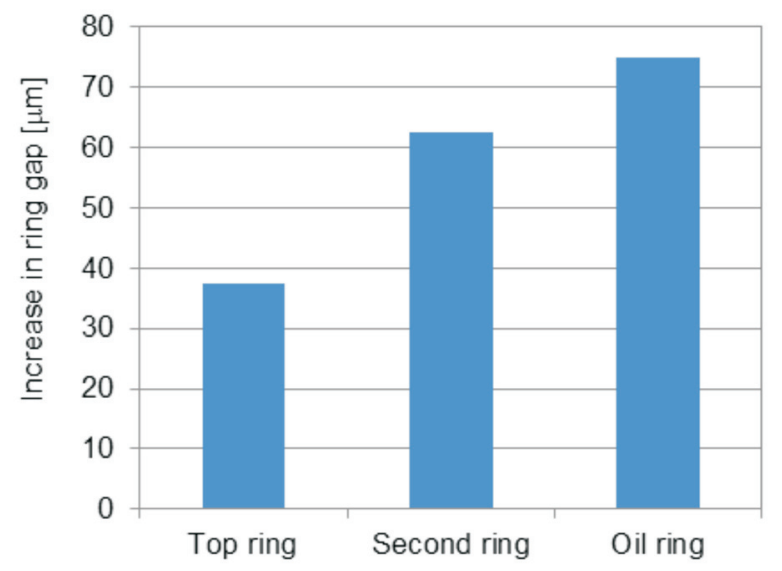

Fig. 7. Increase in ring gap for particular rings during the durability test Rys. 7. Przyrost luzu w zamku dla poszczególnych pierścieni tłokowych podczas testu trwatościowego o 3,4\%, natomiast przy $2000 \mathrm{obr} / \mathrm{min}$ prawie nie zmieniło się (zwiększenie o 0,2\%).

Podobnie jak szybkość zmian w czasie pracy dotartego silnika, również względny spadek zużycia oleju w pierwszym okresie pracy silnika był największy spośród analizowanych parametrów. Wartości zużycia oleju zmierzone po ok. 150 godzinach pracy silnika były mniejsze, w stosunku do wartości uzyskanych w pomiarach przeprowadzonych przed testem trwałościowym, o: $38 \%, 31 \%$ i 10\%, odpowiednio przy obciążeniach $100 \%$, 33\% i $20 \mathrm{~N} \cdot \mathrm{m}$. W tym przedziale czasu natężenie przedmuchów spalin przy małym obciążeniu silnika zmniejszyło się o 3\% przy 2000 obr/min i o 9\% przy $4000 \mathrm{obr} / \mathrm{min}$. Przy pełnym obciążeniu silnika zmniejszenie wartości tego parametru wynosiło: 15\% przy $2000 \mathrm{obr} / \mathrm{min}$ i $12 \%$ przy $4000 \mathrm{obr} / \mathrm{min}$. Z kolei jednostkowe zużycie paliwa w tym okresie, zarówno przy 2000 obr/min, jak i przy $4000 \mathrm{obr} / \mathrm{min}$, zmniejszyło się o 2,5\%. Zmiany mocy były niewielkie: wzrost o 1\% przy $2000 \mathrm{obr} / \mathrm{min}$ i zmniejszenie o $0,5 \%$ przy $4000 \mathrm{obr} / \mathrm{min}$.

Na rysunku 6 przestawiono uśrednione dla wszystkich cylindrów obu silników zużycie tulei cylindrowych (różnice średnic zmierzonych po i przed próbą trwałościową). Średnice tulei cylindrowych w kierunku równoległym do osi silnika uległy niewielkim zmianom, natomiast w kierunku prostopadłym przyrosty średnic były większe, szczególnie w górnej części tulei. Należy przypuszczać, że powyższe zmiany średnic są następstwem zarówno zużycia powierzchni tulei, jak i ich deformacji. Średnie wartości dla obu kierunków wskazują na większe zużycie tulei w okolicach zwrotnych położeń pakietu pierścieniowego, szczególnie górnego zwrotnego położenia. Uzyskane w pomiarach wzrosty luzów w zamkach oraz zmniejszenie wysokości poszczególnych pierścieni tłokowych przestawiono na rys. 7 i 8.

\section{Prognoza trwałości}

Do wyznaczenia przewidywanej trwałości zespołu TPC wykorzystano opracowaną wcześniej metodę $[1,2]$. W metodzie tej ekstrapoluje się zużycie elementów wyznaczone podczas badań silnika i symuluje się odpowiadające im zmiany natężenia przedmuchów spalin, wykorzystując model uszczelnienia pierścieniowego (szczegółowy opis modelu

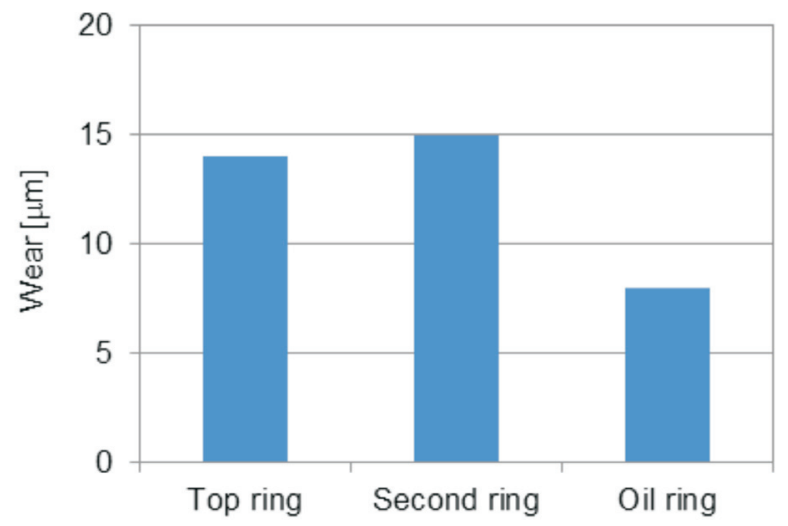

Fig. 8. Changes in rings heights during the durability test Rys. 8. Zmiany wysokości pierścieni podczas testu trwałościowego 


\section{Durability prediction}

To predict the durability of the piston group, a previously developed method was used $[1,2]$. In this method, the wear of particular elements of the piston group obtained during engine testing are extrapolated and then the changes in blow-by caused by the wear are simulated using the ringpack model (a detailed description of the model is presented elsewhere [3]). This way, the wear for which the increase in blow-by achieves a predetermined value is determined. This wear is taken as the boundary wear and the time after which it is achieved is considered to be the predicted durability of the piston group.

Based on the results of the measurements presented above, the courses of wear of particular parts of piston group were determined using a linear extrapolation method (Fig. 9). In the case of the cylinder liner the mean wear on the different heights (Fig. 6) were extrapolated because: a) the cylinder liner wear profile, i.e. wear as a function of distance from the engine head, is required as input data to the model, b) the ring-pack model does not take deviations of circularity into consideration.

Then, the calculations of the blow-by for the different wear states, related to different times of engine operation, were conducted with the use of the ring-pack model. In this method, the time was sought at which the blow-by reached the predetermined limit value. In this study it was assumed that the blow-by can increase by $100 \%$ in relation to the value for a new engine. In the simulation, a twofold increase in the blow-by was obtained for the wear expected after 2020 hours of engine operation. This time is the predicted durability of the piston group according to the used method.

Based on many years of experience, it is accepted that one hour of engine operation during the durability test cor-

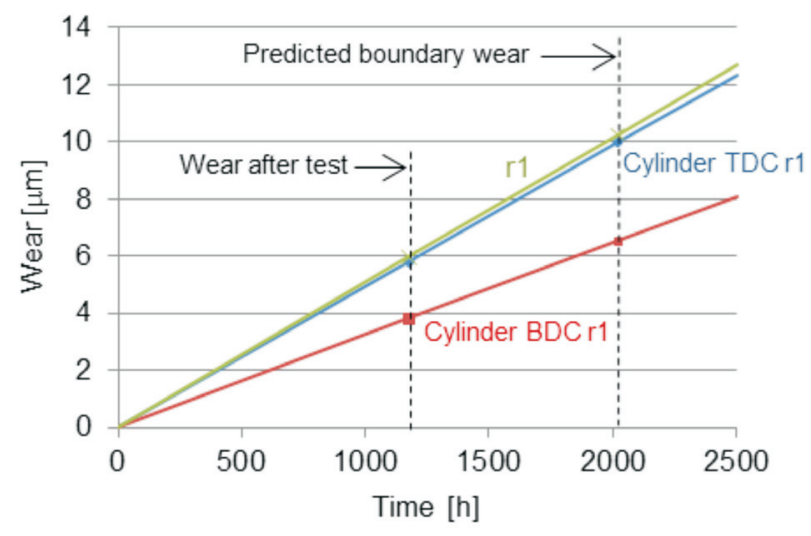

Fig. 9. Courses of wear of selected parts of PRC group: face surface of the top ring ( $\mathrm{r} 1$ ), cylinder at top dead center of top ring (Cylinder TDC r1) and cylinder at bottom dead center of top ring (Cylinder BDC r1); the wear measured after the durability test and predicted boundary wear are marked

Rys. 9. Przebiegi zużycia wybranych elementów zespotu TPC: powierzchni czołowej pierwszego pierścienia (r1), tulei cylindrowej na wysokości GMP pierwszego pierścienia (tuleja GMP r1) oraz tulei cylindrowej na wysokości DMP pierwszego pierścienia (tuleja DMP r1); na rysunku zaznaczono wartości zużycia wyznaczone w pomiarach oraz prognozowane wartości graniczne znajduje się w pracy [3]). W ten sposób poszukuje się takiego zużycia, przy którym wzrost natężenia przedmuchów spalin osiąga założoną wartość. Zużycie to przyjmuje się za zużycie graniczne, a czas, po jakim zużycie takie jest osiągane, odpowiada prognozowanej trwałości zespołu TPC.

Opierając się na opisanych wyżej wynikach pomiarów mikrometrycznych, metodą ekstrapolacji liniowej, wyznaczono przebiegi zużycia poszczególnych elementów zespołu TPC (rys. 9). Dla tulei cylindrowej ekstrapolowano średnie wartości zużycia na poszczególnych wysokościach (patrz rys. 6), gdyż: a) do modelu uszczelnienia, jako dana wejściowa do obliczeń, wprowadzany jest profil zużycia tulei cylindrowej, tj. zużycie w funkcji odległości od głowicy, b) model nie uwzględnia odchyłek okrągłości elementów zespołu TPC.

Następnie, z wykorzystaniem modelu uszczelnienia, przeprowadzano obliczenia natężenia przedmuchów spalin dla różnych wartości zużycia, odpowiadających różnym czasom pracy silnika, poszukując takiego czasu pracy silnika, przy którym przedmuchy osiągnęły wartość graniczną. W niniejszych obliczeniach przyjęto, że przedmuchy mogą zwiększyć się o $100 \%$, w stosunku do wartości uzyskanych dla nowego silnika. W symulacjach numerycznych dwukrotny wzrost natężenia przedmuchów uzyskano dla zużycia przewidywanego po 2020 godzinach pracy silnika. Czas ten jest prognozowaną trwałością układu TPC według zastosowanej metody.

Na podstawie wieloletnich doświadczeń przyjmuje się, że 1 godzina pracy silnika w wykorzystanym w badaniach teście trwałościowym odpowiada ok. $150 \mathrm{~km}$ przebiegu samochodu. Oznacza to, że trwałość układu TPC badanego silnika oceniono na $303000 \mathrm{~km}$.

\section{Podsumowanie}

Wyznaczono zmiany mocy, jednostkowego zużycia paliwa i szczelności układu tłok-pierścienie-cylinder, a także zużycie elementów zespołu TPC nowoczesnego silnika samochodowego o zapłonie samoczynnym podczas długotrwałego stanowiskowego testu trwałościowego. Wartości analizowanych parametrów uległy poprawie w pierwszym okresie pracy silnika, co należy wiązać z jego docieraniem, po czym zaczęły ulegać stopniowemu pogarszaniu, przy czym względne zmiany były różne dla różnych parametrów.

Najszybciej wraz z czasem pracy silnika zmieniało się zużycie oleju silnikowego. W pierwszym okresie pracy silnika (0-150 godzin) zużycie oleju zmniejszyło się o 25\%, natomiast w przedziale czasu pracy 100-1200 godzin wzrosło o ponad $100 \%$. Zmiany natężenia przedmuchów spalin zależały od warunków pracy silnika. Średnio w pierwszym okresie natężenie przedmuchów zmniejszyło się o 10\%, a na koniec testu, w stosunku do stanu po 100 godzinach czasu pracy, wzrosło o ponad 35\%. Względne zmiany osiągów i sprawności były dużo mniejsze. Jednostkowe zużycie paliwa w pierwszym okresie zmniejszyło się o 2,5\%, a na koniec testu wzrosło o niecałe $2 \%$. Moc natomiast niemal nie uległa zmianie w pierwszym okresie (wzrost o 0,3\%), a na koniec testu była mniejsza o 2,5\% od wartości uzyskanej po 100 godzinach czasu pracy silnika. 
responds to about $150 \mathrm{~km}$ of distance covered by a car. This means that the durability of the piston group of the tested engine was evaluated as $303,000 \mathrm{~km}$.

\section{Summary}

The changes in power, specific fuel consumption and tightness of the ring-pack, as well as wear of the piston group elements of a modern car diesel engine during durability testing were determined. The values of the above parameters got better in the first period of engine work, which was connected with the run-in of the engine, and then they started to worsen gradually. However, the relative changes were different for different parameters.

The oil consumption changed the quickest of all the parameters analysed. In the first period of engine operation ( $0-150$ hours) the oil consumption dropped by about $25 \%$, while in the 100-1200 hours range, it increased by over $100 \%$. The changes in the blow-by depended on the condition of the engine operation. On average, in the first period, the blow-by decreased by about $10 \%$, and at the end of the test, was over 35\% higher than after 100 hours. Relative changes in engine performance and efficiency were much smaller. Specific fuel consumption decreased by $2.5 \%$, during the first period, and increased by less than $2 \%$ at the end of the test. In turn, the power almost didn't change in the first period (an increase of $0.3 \%$ ), and at the end of the test it was $2.5 \%$ lower than after 100 hours of engine operation.

Using the results of wear measurements and the previously developed method, the durability of the piston group of the tested engine was predicted. At the assumed criterion of the boundary state (a twofold increase in blow-by), and assuming 1 hour of engine operation in the durability test to be equivalent to $150 \mathrm{~km}$ car mileage (following the manufacturer of the test engine), the durability of the piston group was evaluated at $300,000 \mathrm{~km}$.

The determined durability of the piston group is comparable with the durability determined in the same way for the lower power $(55 \mathrm{~kW})$ version of the engine [2]. The wear of the cylinder liners of the more exerted engine (of higher power) was bigger than in the lower power version, especially in the ring-pack TDC region. On the other hand, the wear of the ring faces, especially in the case of the top ring, was lower for the higher power version. The rate of increase of blow-by and oil consumption as a function of engine operating time, were similar for both versions, however the absolute values were higher for the higher power version $[2,4]$.
Wykorzystując wyniki przeprowadzonych pomiarów zużycia oraz opracowaną wcześniej metodę, wyznaczono trwałość zespołu TPC badanego silnika. Przy założonym kryterium stanu granicznego (dwukrotny wzrost natężenia przedmuchów spalin) oraz przyjmując, za producentem silnika, że jedna godzina pracy silnika w teście odpowiada 150 km przebiegu samochodu, trwałość zespołu TPC oceniono na $300000 \mathrm{~km}$.

Wyznaczona trwałość zespołu TPC jest porównywalna $\mathrm{z}$ trwałością wyznaczoną w ten sam sposób dla mniej wysilonej (55 kW) wersji badanego silnika [2]. Zużycie gładzi cylindrowych bardziej wysilonej wersji silnika było większe, niż wersji o mniejszej mocy maksymalnej, szczególnie na wysokości górnego zwrotnego położenia części pierścieniowej tłoka. Z kolei zużycie czołowych powierzchni pierścieni, W szczególności pierwszego pierścienia uszczelniającego i pierścienia zgarniającego, w wersji o większej mocy było mniejsze. Szybkości zwiększania się natężenia przedmuchów spalin i zużycia oleju silnikowego następujące wraz z upływem czasu pracy silnika były zbliżone dla obu wersji silnika, z tym że bezwzględne wartości dla silnika o większej mocy były większe $[2,4]$.

\section{Bibliography/Literatura}

[1] Koszałka G. Predicting the durability of the piston-ringscylinder assembly of a diesel engine using a piston ring pack model. Eksploatacja i Niezawodność - Maintenance and Reliability, 3 (51), 2011, 40-44.

[2] Koszałka G., Suchecki A. Durability prediction of a diesel engine piston-rings-cylinder assembly on the basis of test bench results. SAE Technical Paper 2011-24-0130, 2011.

[3] Koszałka G., Guzik M. Mathematical model of piston ring sealing in combustion engine. Polish Maritime Research, 4 (84), 2014, 66-78.

[4] Koszałka G., Suchecki A. Changes in blow-by and compression pressure of a diesel engine during a bench durability test. Combustion Engines, 3 (154), 2013, 34-39.

[5] Krysicki W. i in. Rachunek prawdopodobieństwa i statystyka matematyczna w zadaniach, cz. II: Statystyka matematyczna. PWN, Warszawa 1994.
Grzegorz Koszałka, DEng. - Assistant Professor in the Faculty of Mechanical Engineering at Lublin University of Technology.

Dr inż. Grzegorz Koszalka - adiunkt na Wydziale Mechanicznym Politechniki Lubelskiej.

e-mail: g.koszalka@pollub.pl

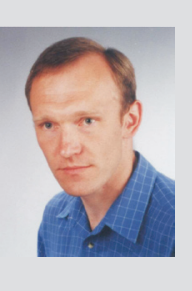

Andrzej Suchecki, DEng. - Head of Engine Testing Laboratory at Automotive Research and Development Institute BOSMAL in Bielsko-Biała.

Dr inż. Andrzej Suchecki-kierownik Pracowni Badań Stanowiskowych Silników w Instytucie Badań i Rozwoju Motoryzacji BOSMAL Sp. z o.o. w Bielsku Białej. e-mail: andrzej.suchecki@bosmal.com.pl

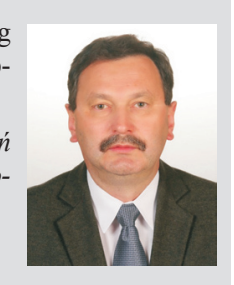

